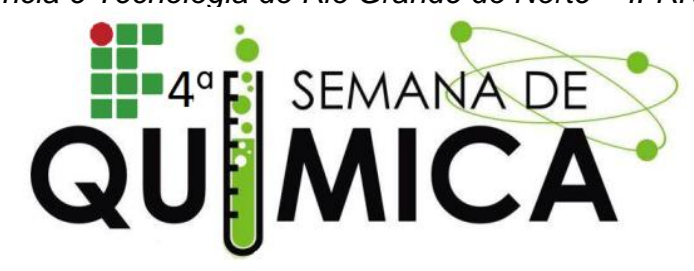

\title{
MEDIÇÃO DA QUANTIDADE DE_CALORIAS CONTIDA EM ALGUNS ALIMENTOS A PARTIR DE UM CALORÍMETRO ARTESANAL
}

SILVA, H.N.A. (IFRN), LIMA, L.K.C.S. (IFRN), SENA; C.P.S. (IFRN), OLIVEIRA, M.M.O. (IFRN), TERCEIRO, J.F. (EEDLN).

Palavras Chave: Experimentação, contextualização, Calorímetro Artesanal.

\section{INTRODUÇÃO}

Segundo a Associação Brasileira das Refeições Coletivas - ABERC - (2008 apud), ACCIOLY, 2009 o tema alimento pode ser inserido no processo educativo de forma interdisciplinar, de modo a estabelecer aprendizagem em todas as áreas do conhecimento. Tendo em vista que a experimentação pode promover uma aprendizagem significativa para o ensino de Química (BRASIL, 2000), o presente trabalho buscou utilizar a experimentação para promover uma educação alimentar atrelada ao conteúdo Termoquímica. Assim, realizou-se uma atividade experimental baseada na construção de um calorímetro artesanal, o qual foi utilizado como material didático para realizar uma discussão acerca dos alimentos mais e menos calóricos em consonância com suas transformações químicas, (ganho e queima).

\section{METODOLOGIA}

O trabalho foi aplicado no $2^{\circ}$ ano do ensino médio de uma escola em Marcelino Vieira-RN. A aplicação foi realizada em 2 momentos, conforme o fluxograma 01:

Fluxograma 01: Metodologia das atividades propostas.

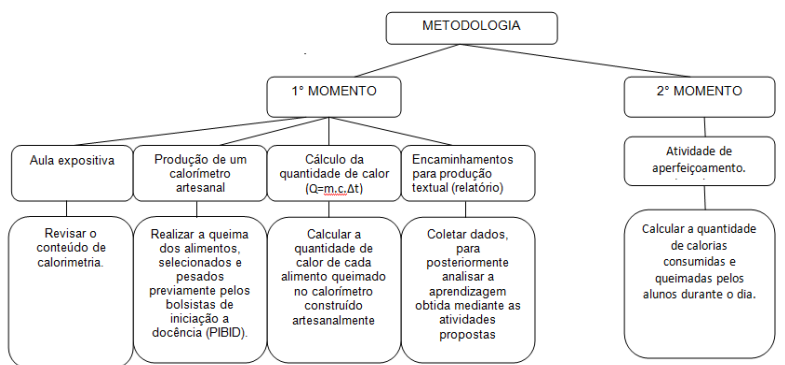

A avaliação da aprendizagem foi realizada através de observações referente à participação e discussões nas aulas; produção do calorímetro; resolução dos exercícios e na produção textual (relatório).
Figura 01: Alunos realizando o experimento através do calorímetro artesanal.

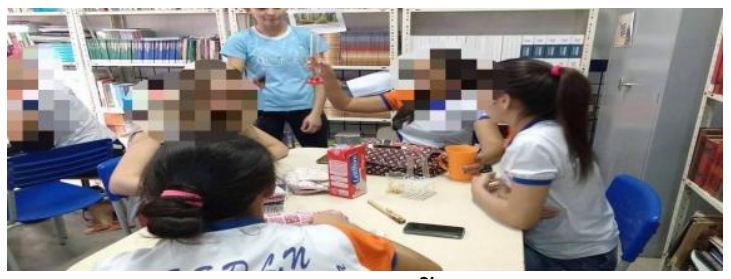

RESULTADOS E DISCUSSÕES

$\mathrm{Na}$ aula expositiva, objetivando contextualizar o assunto de calorimetria foi sugerido trabalhar a experimentação através de um calorímetro artesanal, o que despertou o interesse e motivação da turma. Na sequência, mediante o roteiro e a orientação dos bolsistas, os alunos conseguiram produzir o calorímetro a partir da reutilização de caixas de leite. Em seguida, ainda sob orientação, manusearam vidrarias e conseguiram produzir a combustão dos alimentos e calcular a quantidade de calorias de ambos ( $\mathrm{Q}=\mathrm{m} . \mathrm{c} . \Delta \mathrm{t})$. De acordo com as discussões e atividades propostas (exercícios e relatório), verificou-se ao fim da aplicação que houve uma participação efetiva dos alunos e, consequentemente, uma melhoria na aprendizagem dos conceitos trabalhados.

CONCLUSÃO

Portanto, conclui-se que a experimentação de forma contextualizada com temas pertinentes ao cotidiano do aluno, leva-os a uma maior motivação e, consequentemente, a uma aprendizagem mais efetiva sobre a temática em estudo.

REFERÊNCIAS

${ }^{1}$ BRASIL.Parâmetros Curriculares Nacionais do Ensino Médio. Brasília: MEC; SEMTEC, 2000.

${ }^{2}$ ACCIOLY, Elizabeth. A escola como promotora da alimentação saudável. Ciência em tela, Rio de Janeiro, v.2, n.2, p. 01-09, Jun. 2009. 